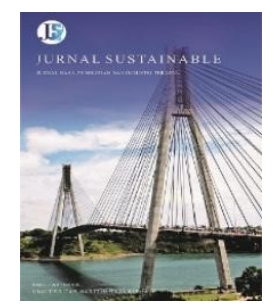

\title{
Monitoring Keasaman dan Kekeruhan Air menggunakan Mikrokontroler Berbasis Internet of Things
}

\author{
Sapta Nugraha ${ }^{1, *}$, Rifki Triaditiya Putra ${ }^{2}$, Rozeff Pramana ${ }^{3}$, Hollanda Arief Kusuma ${ }^{4}$, Tonny \\ Suhendra ${ }^{5}$, Eko Prayetno ${ }^{6}$, Deny Nusyirwan ${ }^{7}$ \\ 1,2,3,4,5,6,7 Jurusan Teknik Elektro, Fakultas Teknik, Universitas Maritim Raja Ali Haji \\ ${ }_{1,2,3,4,5,6,7}$ Jl. Politeknik Senggarang, Tanjungpinang 29100 \\ *Corresponding Author: saptanugraha@umrah.ac.id
}

\begin{abstract}
The quality and quantity standards of drinking water are tasteless and not cloudy. This study aimed to design the monitoring of water acidity and turbidity using a microcontroller based on the Internet of Things. The system device uses a pH sensor and a turbidity sensor to measure the water's edge and turbidity. The results show that the water acidity and turbidity monitor has been successfully designed using OLED and GSM displayed on the Thingspeak platform. This display shows the results of testing the $\mathrm{pH}$ value with an average accuracy level of $96.34 \%$ and the turbidity sensor $97.33 \%$. The monitoring data transmission results using the GSM network to the Thingspeak platform were $95.83 \%$ in the first test and $90.97 \%$ in the second test.
\end{abstract}

Keywords-Monitoring, acidity, turbidity, microcontroller, Internet of Things.

Intisari-Standar kualitas dan kuantitas air konsumsi antara lain tidak berasa dan tidak keruh. Tujuan dari penelitian ini adalah merancang monitoring keasaman dan kekeruhan air menggunakan mikrokontroler berbasis Internet of Things. Perangkat sistem menggunakan sensor $\mathrm{pH}$ dan sensor turbidity sebagai pengukur keasaman dan kekeruhan air. Hasil penelitian menunjukkan bahwa perangkat monitoring keasaman dan kekeruhan air berhasil dirancang dengan menggunakan OLED dan GSM yang ditampilkan ke dalam platform Thingspeak. Tampilan menunjukkan hasil pengujian nilai $\mathrm{pH}$ dengan tingkat akurasi rata-rata sebesar $96,34 \%$ dan sensor turbidity sebesar 97,33\%. Hasil uji monitoring pengiriman data menggunakan jaringan GSM ke platform Thingspeak sebesar 95,83\% pada pengujian pertama dan sebesar $90,97 \%$ pada pengujian kedua.

Kata kunci-Monitoring, keasaman, kekeruhan, mikrokontroler, Internet of Things.

\section{Pendahuluan}

Kebutuhan air diukur berdasarkan kebutuhan energi per hari (kkal/hari). Umumnya, anak-anak membutuhkan asupan rata-rata untuk cairan berkisar $1.300 \mathrm{ml} /$ hari dengan kebutuhan energi diperkirakan $1.000-1.400 \mathrm{kkal} / \mathrm{hari}$. Sedangkan, asupan rata-rata untuk cairan yang dibutuhkan perempuan dewasa sekitar 2.700 $\mathrm{ml} /$ hari dengan kebutuhan energi diperkirakan antara $2.000-2.200 \mathrm{kkal} / \mathrm{hari}$ dan laki-laki dewasa sekitar $3.700 \mathrm{ml} /$ hari dengan kebutuhan energi antara $2.400-2.800 \mathrm{kkal} / \mathrm{hari}$ [1].

Peningkatan kebutuhan makhluk hidup akan air layak konsumsi juga berimbang dengan pertumbuhan makhluk hidup terutama manusia sehingga mengakibatkan kondisi air layak konsumsi semakin berkurang [2]. Keadaan air layak konsumsi yang terus berkurang menjadi ancaman bagi manusia sebagai konsumen. Sehingga, banyak cara yang dilakukan oleh manusia dalam memperoleh air layak konsumsi 
tersebut. Namun, beberapa cara yang dilakukan dalam mengatasi permasalahan ini tidak sepenuhnya benar dan dapat menimbulkan penyakit bagi manusia. Berdasarkan penelitian yang dilakukan, salah satu caranya dengan menjadikan air galian ataupun air genangan hujan di lahan sebagai air olahan yang kemudian dijual kepada masyarakat. Beberapa masyarakat akan menggunakan air tersebut sebagai air minum mereka. Selain itu juga, penggunaan air sumur sebagai sumber mata air masyarakat juga akan digunakan masyarakat untuk mengatasi hal tersebut.

Penggunaan air galian ataupun air genangan hujan di lahan serta air sumur tentu saja memiliki parameter kualitas dan kuantitas yang belum jelas kelayakannya untuk dikonsumsi manusia. Kualitas dan kuantitas dalam penyediaan air layak konsumsi harus memenuhi standar Peraturan Kementerian Kesehatan RI No. 492/Menkes/Per/IV/2010 tentang Persyaratan Kualitas Air Minum. Persyaratan kualitas dan kuantitas penyediaan air layak konsumsi antara lain tidak berasa, tidak berbau dan tidak keruh [3].

Penentuan kualitas dan kuantitas air layak konsumsi tentu saja membutuhkan sebuah teknologi. Teknologi tersebut adalah teknologi yang mampu melakukan pengukuran suatu air layak atau tidak untuk dikonsumsi bagi manusia berdasarkan persyaratan parameter yang ditentukan. Dalam era revolusi industri 4.0, pengukuran air layak konsumsi bisa dilakukan dengan pemantauan jarak jauh menggunakan jaringan internet berbasis web atau yang dikenal dengan Internet of Things (IoT). Internet of Things merupakan kemampuan sebuah teknologi yang memungkinkan adanya sebuah komunikasi, pengendalian serta kerja sama antara perangkat keras dan data melalui jaringan internet.[4]

Oleh sebab itu, perancangan alat pemantauan keasaman dan kekeruhan air tersebut sebaiknya mudah untuk digunakan dan memiliki tingkat akurasi yang baik. Selain itu, hasil keluaran yang diukur juga dapat dipantau menggunakan platform IoT yaitu Thingspeak agar dapat diakses menggunakan smartphone.

\section{Perancangan Sistem}

\section{A. Perancangan Sistem}

Perancangan merupakan tahap yang paling penting dari keseluruhan proses pembuatan suatu perangkat. Perancangan ini dapat dilihat pada Gambar 1, terdiri dari 4 bagian utama yaitu:

1) Bagian catu daya atau power supply terdiri dari sumber daya yang digunakan adalah satu buah powerbank dengan daya sebesar $12.500 \mathrm{mAH}$.

2) Bagian input terdiri dari sensor $\mathrm{pH}$ untuk mendapatkan nilai data $\mathrm{pH}$ asam ataupun basa dan sensor turbidity (kekeruhan air) untuk mendapatkan nlai data kekeruhan air dalam satuan NTU.

3) Bagian proses terdiri dari mikrokontroler Arduino Nano dengan fungsi untuk mengolah data, melakukan perhitungan dan melakukan proses yang menjadi otak dalam perangkat.

4) Bagian output terdiri dari bagian pengiriman data dari hasil proses oleh Arduino Nano ke OLED yang dapat diakses oleh pengguna melalui perangkat dan GSM yang dapat diakses oleh pengguna melalui smartphone.

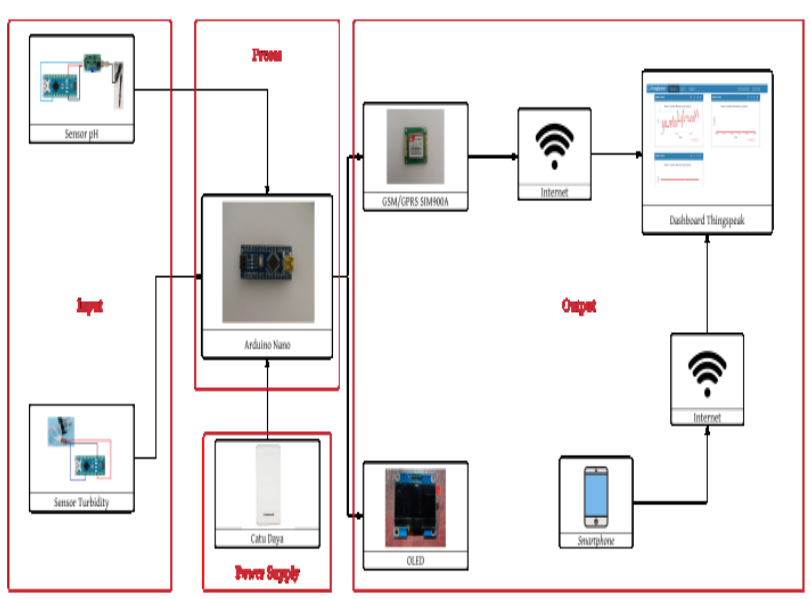

Gambar 1. Diagram perancangan sistem

\section{B. Proses Pengujian Sistem}

Proses pengujian dilakukan dengan menghidupkan perangkat yang diujikan dan diletak pada wadah penampungan yang berisikan air PDAM dan air sumur. Pengujian dilakukan 
dalam waktu 1 × 24 jam dengan menguji alat dengan sampel yang digunakan guna memperoleh nilai yang memiliki akurasi dan presisi yang tepat sesuai yang dilakukan saat pengujian menggunakan kalibrator standar. Proses pengujian sensor dan kalibrator dilakukan di Laboratorium Kimia Universitas Maritim Raja Ali Haji dan pengujian perangkat penelitian dilakukan di rumah warga yang menggunakan air PDAM sebagai sumber air untuk dikonsumsi.
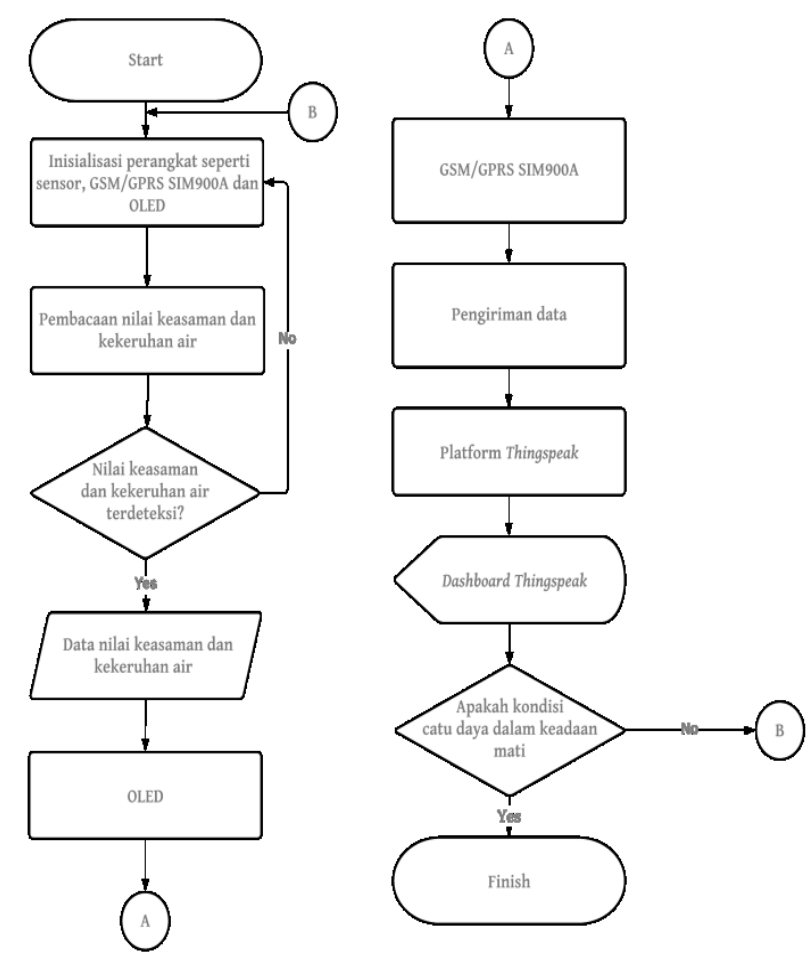

Gambar 2. Diagram alir sistem kerja

\section{Cara Kerja Sistem}

Pada perangkat ini, power supply yang digunakan yaitu sumber pada mikrokontroler. Power supply yang digunakan yaitu powerbank $12.500 \mathrm{mAH}$. Ketika perangkat telah dihubungkan dengan power supply, perangkat akan diletakkan di lokasi pengujian sistem keseluruhan yaitu di penampungan air PDAM dan air sumur dengan keadaan wadah berada di bidang datar.

Jika pada wadah tersebut mengandung air yang terdapat sifat keasaman dan kekeruhan, mikrokontroler akan menerima data yang telah ditangkap oleh sensor dan mengolah data tersebut yang kemudian dikirimkan ke OLED untuk ditampilkan. Cara kerja sistem dapat dilihat pada Gambar 2.

\section{Pengujian dan Analisis}

\section{A. Pengujian Kalibrasi Sensor $p H$}

Pengujian kalibrasi Sensor $\mathrm{pH}$ dilakukan guna mengetahui selisih antara modul sensor $\mathrm{pH}$ Electrode E201-BNC dan $\mathrm{pH}$ meter Lovibond. Modul $\mathrm{pH}$ meter Lovibond digunakan sebagai pembanding pengukuran sensor $\mathrm{pH}$ Electrode E201-BNC. Sehingga, hasil dari kedua perbandingan alat ukur tersebut akan menjadi acuan pada penelitian ini.

Pengujian sensor $\mathrm{pH}$ dilakukan di Laboratorium Kimia UMRAH dengan melakukan uji setiap sampel terhadap kalibrator $\mathrm{pH}$ meter dengan jumlah sebanyak 5 jenis sampel $\mathrm{pH}$ yaitu air jeruk sebesar $\mathrm{pH} 2$, air sadah sebesar $\mathrm{pH} \mathrm{4,} \mathrm{air} \mathrm{teh} \mathrm{sebesar} \mathrm{pH} 5$, air sumur sebesar $\mathrm{pH} 6$ dan air mineral sebesar $\mathrm{pH}$ 7. Pola scatter masing-masing tegangan inputan analog sampel $\mathrm{pH}$ diperoleh pola metode regresi linear yang ditunjukkan Gambar 3.

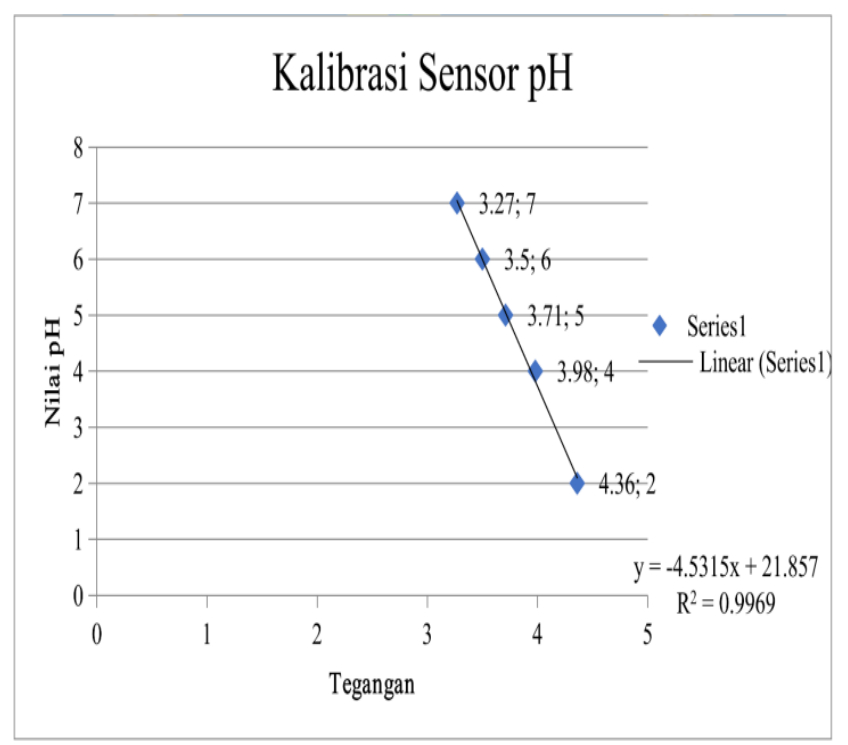

Gambar 3. Grafik kalibrasi sensor $\mathrm{pH}$

Kemudian, Uji sampel dilakukan sebanyak 10 kali pengujian yang mana 1 kali pengujian berlangsung selama 2 menit sehingga total dari 20 kali pengujian sampel berlangsung selama 10 menit. Hal ini dilakukan karena sensor membutuhkan waktu selama \pm 2 menit untuk mendapatkan nilai uji sampel yang mendekati nilai uji kalibrator dan terukur stabil. 
Berdasarkan uji sampel tersebut, Nilai $\mathrm{pH}$ yang diperoleh pada sensor $\mathrm{pH}$ Electrode E201-BNC ditampilkan pada tampilan OLED yang pengambilan datanya diproses oleh Arduino Nano. Hasil pengujian dapat dikonversikan menggunakan persamaan pada Gambar 3 yang bertujuan untuk mengetahui nilai perbandingan pengujian antara $\mathrm{pH}$ meter dan sensor $\mathrm{pH}$. Nilai rata-rata perbandingan uji sampel pengujian antara $\mathrm{pH}$ meter dan sensor $\mathrm{pH}$ dapat dilihat pada Tabel 1.

Tabel 1. Perbandingan sensor $\mathrm{pH}$ dan $\mathrm{pH}$ meter

\begin{tabular}{ccccc}
\hline Sampel & $\begin{array}{c}\text { pH } \\
\text { Meter }\end{array}$ & $\begin{array}{c}\text { Sensor } \\
\text { pH }\end{array}$ & $\begin{array}{c}\text { Error } \\
\text { (\%) }\end{array}$ & $\begin{array}{c}\text { Akurasi } \\
\text { (\%) }\end{array}$ \\
\hline pH 2 & 2,00 & 2,15 & 7,30 & 92,70 \\
pH 3 & 4,00 & 3,84 & 4,13 & 95,88 \\
pH 4 & 5,00 & 4,94 & 1,20 & 98,80 \\
pH 5 & 6,00 & 6,13 & 2,17 & 97,83 \\
pH 6 & 7,00 & 7,25 & 3,50 & 96,50 \\
& Rata-rata & & 3,66 & 96,34 \\
\hline
\end{tabular}

\section{B. Pengujian Kalibrasi Sensor Turbidity}

Pengujian sensor turbidity dilakukan guna menguji larutan air yang terukur yang mengalami perubahan dalam proses pengambilan datanya dengan tempo waktu 20 menit serta pemantauan data di setiap 2 menitnya. Sifat gravitasi bumi dan pencahayaan ruangan sangat berpengaruh dalam melakukan pengujian sensor kekeruhan air ini.

Pengujian sensor kekeruhan air dilakukan di Laboratorium Kimia UMRAH dengan melakukan uji setiap sampel terhadap kalibrator turbidimeter dengan jumlah sebanyak 10 jenis sampel air yaitu air PDAM sebesar 0 NTU, air

Sumur sebesar 0,81 NTU, air sadah sebesar 1,62 NTU, serta larutan kalibrator sebesar 3 NTU, 4,5 NTU, 6 NTU, 7,5 NTU, 9 NTU, 10,5 NTU, dan 12 NTU. Dari pola scatter masing-masing tegangan inputan analog sampel kekeruhan air diperoleh pola metode polinomial dan didapatkan juga persamaan sebagai berikut.

Kemudian, Uji sampel dilakukan sebanyak 10 kali pengujian yang mana 1 kali pengujian berlangsung selama 2 menit sehingga total dari 10 kali pengujian sampel berlangsung selama 20 menit. Hal ini dilakukan karena sensor membutuhkan waktu selama \pm 2 menit untuk mendapatkan nilai uji sampel yang mendekati nilai uji kalibrator dan terukur stabil.

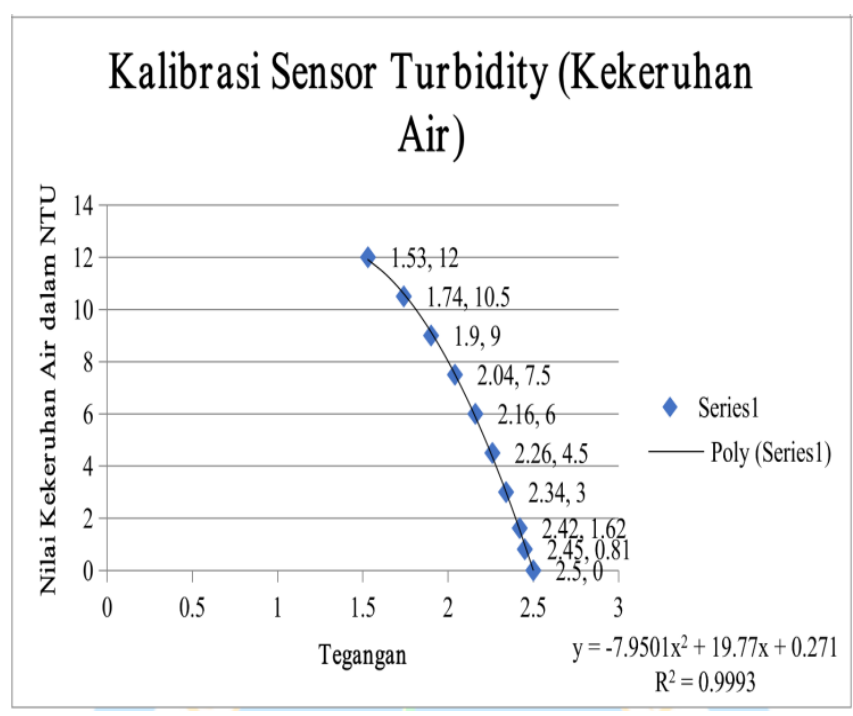

Gambar 4. Grafik kalibrasi sensor turbidity

Berdasarkan uji sampel tersebut, Nilai kekeruhan air yang diperoleh pada sensor kekeruhan air ditampilkan pada tampilan OLED yang pengambilan datanya diproses oleh Arduino Nano. Hasil pengujian dapat dikonversikan menggunakan persamaan pada Gambar 4 yang bertujuan untuk mengetahui nilai perbandingan pengujian antara turbidimeter dan sensor turbidity. Nilai rata-rata perbandingan uji sampel pengujian antara turbidimeter dan sensor turbidity dapat dilihat pada Tabel 2.

Tabel 2. Perbandingan uji sensor turbidity dan turbidimeter

\begin{tabular}{ccccc}
\hline $\begin{array}{c}\text { Sampel } \\
\text { NTU }\end{array}$ & Tmeter & TSensor & $\begin{array}{c}\text { Error } \\
(\%)\end{array}$ & $\begin{array}{c}\text { Akurasi } \\
(\%)\end{array}$ \\
\hline 0 & 0,00 & 0,07 & 7,00 & 93,00 \\
0,81 & 0,81 & 0,83 & 6,42 & 93,58 \\
1,62 & 1,62 & 1,63 & 5,19 & 94,81 \\
3 & 3,00 & 3,02 & 2,83 & 97,17 \\
4,5 & 4,50 & 4,53 & 1,91 & 98,09 \\
6 & 6,00 & 6,01 & 1,03 & 98,97 \\
7,5 & 7,50 & 7,54 & 0,87 & 99,13 \\
9 & 9,00 & 9,05 & 0,72 & 99,28 \\
10,5 & 10,50 & 10,53 & 0,50 & 99,50 \\
12 & 12,00 & 11,99 & 0,27 & 99,73 \\
\multicolumn{5}{c}{ Rata-rata Nilai } \\
\hline
\end{tabular}




\section{Pengujian Keseluruhan Sistem Pertama}

Pengujian sistem secara keseluruhan yang pertama ini dilakukan untuk mengetahui proses pengiriman data yang dilakukan pada

lokasi pertama yaitu penampungan warga yang menggunakan air PDAM. Pengujian ini dilakukan dalam 1 hari dengan waktu 1 x 24 jam. Data yang diolah mikrokontroler kemudian ditampilkan menggunakan OLED dan diteruskan dengan pengiriman data. Pengiriman data hanya dilakukan dengan menggunakan SIM900A ke ke platform Thingspeak, sehingga tingkat keberhasilan pengiriman data bergantung pada kualitas sinyal dari lokasi tersebut. Hasil yang ditunjukkan pada platform Thingspeak berupa waktu, jumlah data, $\mathrm{pH}$ dan kekeruhan air. Jika perngiriman data berhasil, data yang ada akan muncul di dashboard Thingspeak, sedangkan jika tidak berhasil maka data tersebut akan hilang/tidak terbaca. Hasil dari pengujian sistem secara keseluruhan yang pertama dapat dilihat pada Gambar 5 yang menggambarkan garis biru sebagai nilai $\mathrm{pH}$ dan garis jingga sebagai nilai turbidity.

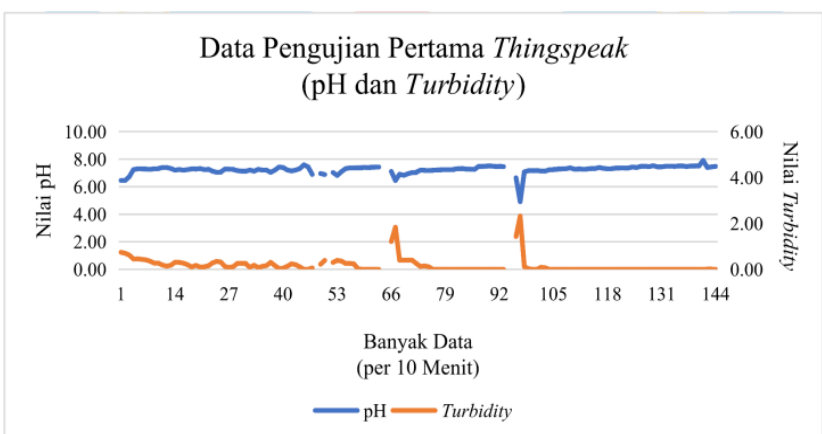

Gambar 5. Grafik data $\mathrm{pH}$ dan turbidity di Thingspeak pada air PDAM

Pengujian pertama sistem dilakukan dengan cara mengirim 2 hasil data per menit. 1 hasil data tersebut terkirim per 25 detik sekali ke Thingspeak sehingga diperoleh ribuan data dalam kurun waktu 24 jam. Oleh sebab itu, rentang interval pengambilan data kemudian diubah dengan mengambil data per 10 menit sekali dengan total data sebanyak 144 data selama 24 jam, agar data yang ditampilkan dalam grafik lebih mudah terbaca. Data tersebut akhirnya didapatkan sebanyak 138 data yang terkirim dan tersimpan di Thingspeak. Namun, sebanyak 6 data tidak dapat terkirim ke Thingspeak.

Hal ini diperkirakan terjadi karena penurunan kualitas sinyal operator yang digunakan pada GSM/GPRS Shield SIM900A saat pengiriman data walaupun rata-rata dari hasil kualitas sinyal atau RSSI pada lokasi pengujian sistem keseluruhan pertama sebesar $59 \mathrm{dBm}$ atau dalam kategori sangat baik. Selain itu, delay yang terjadi saat pengiriman data yang hilang mengalami perbedaan delay yang cukup besar melebihi delay yang telah diprogram sebesar 25 detik sehingga semakin besar delay yang digunakan maka semakin banyak pula data yang akan hilang. Grafik putus-putus yang terdapat pada Gambar 5 membuktikan bahwa pada saat data memasuki rentang interval 10 menit ke-53, 10 menit ke-66 dan 10 menit ke-45 data tidak diterima oleh Thingspeak.

Dari gambar tersebut pula diperoleh Nilai pH tertinggi terdapat pada data ke-141 sebesar 7,91 dan nilai $\mathrm{pH}$ terendah diperoleh pada data ke-97 sebesar 4,92. Sedangkan, nilai turbidity tertinggi diperoleh pada data ke-97 sebesar 2,32 NTU dan nilai turbidity terendah sebesar 0 NTU.

Berdasarkan hasil data pengujian tersebut diperoleh bahwa peningkatan nilai tertinggi kekeruhan air berbanding terbalik dengan nilai $\mathrm{pH}$ yang mengalami penurunan. Sedangkan untuk rasio keberhasilan pengiriman data, rasio penerimaan data yang terikirim pada website Thingspeak ataupun Thingview saat pengujian sistem keseluruhan pertama sebesar 95,83\%.

\section{Pengujian Keseluruhan Sistem Kedua}

Pengujian sistem secara keseluruhan yang kedua ini dilakukan untuk mengetahui proses pengiriman data yang dilakukan pada lokasi kedua yaitu perumahan warga yang menggunakan air sumur. Pengujian ini dilakukan dalam 1 hari dengan waktu 1 x 24 jam. Data yang diolah mikrokontroler kemudian ditampilkan menggunakan OLED dan diteruskan dengan pengiriman data. Pengiriman data hanya dilakukan dengan menggunakan SIM900A ke platform Thingspeak, sehingga tingkat keberhasilan pengiriman data bergantung pada kualitas sinyal dari lokasi tersebut. Hasil yang ditunjukkan pada platform Thingspeak berupa 
waktu, jumlah data, $\mathrm{pH}$ dan kekeruhan air. Jika perngiriman data berhasil, data yang ada akan muncul di dashboard Thingspeak, sedangkan jika tidak berhasil maka data tersebut akan hilang/tidak terbaca. Hasil dari pengujian sistem secara keseluruhan yang kedua dapat dilihat pada Gambar 6.

Pengujian kedua sistem dilakukan dengan cara yang sama pada pengujian sistem keseluruhan yang pertama dengan mengambil data per 10 menit sekali. Data yang dikirim didapatkan sebanyak 131 data yang terkirim dan tersimpan di Thingspeak. Namun, sebanyak 13 data tidak dapat terkirim ke Thingspeak.

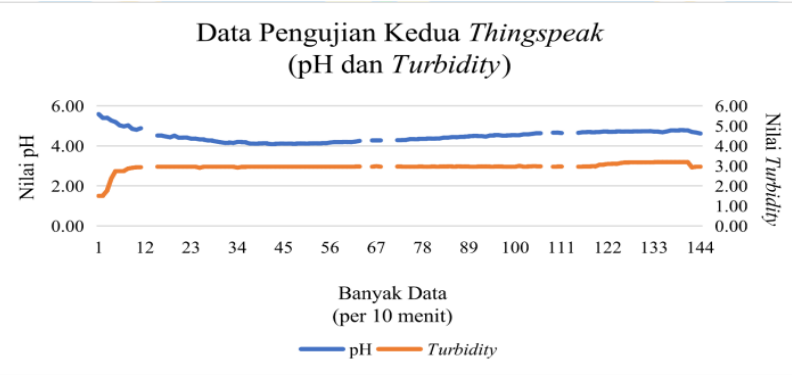

Gambar 6. Grafik data pH dan turbidity di Thingspeak pada air sumur

Hal ini juga diperkirakan terjadi karena penurunan kualitas sinyal operator yang digunakan pada GSM/GPRS Shield SIM900A saat pengiriman data serta rata-rata dari hasil kualitas sinyal atau RSSI pada lokasi pengujian sistem keseluruhan kedua sebesar $-89 \mathrm{dBm}$ atau dalam kategori cukup. Grafik putus-putus yang terdapat pada Gambar 6 membuktikan bahwa pada saat data memasuki rentang interval 10 menit ke-12, antara 10 menit ke-67 dan 10 menit ke-78, serta 10 menit ke-111 dan 10 menit ke122 delay yang terjadi saat pengiriman data sangat besar melebihi dari delay yang diprogramkan sehingga data dapat tidak diterima oleh Thingspeak.

Gambar 6 memiliki nilai $\mathrm{pH}$ tertinggi terdapat pada data ke-1 sebesar 5,59 dan nilai $\mathrm{pH}$ terendah diperoleh pada data ke-45 sebesar 4,09. Sedangkan, nilai turbidity tertinggi diperoleh pada data ke-136 sebesar 3,19 NTU dan nilai turbidity terendah diperoleh pada data ke-1 sebesar 1,50 NTU.
Berdasarkan hasil data pengujian sistem keseluruhan kedua, nilai tertinggi yang diperoleh kekeruhan air hampir sama dengan pengujian sistem keseluruhan pertama yang perbedaannya hanya terletak pada urutan data yaitu data ke-1. Hal ini juga berbanding terbalik dengan nilai $\mathrm{pH}$ yang mengalami titik terendah pada data ke-1. Sedangkan untuk rasio pengiriman data, rasio penerimaan data yang terkirim pada website Thingspeak ataupun Thingview saat pengujian sistem keseluruhan kedua sebesar 90,97\%.

Berdasarkan hasil pengujian sistem keseluruhan pertama dan kedua, hasil dari kedua pengujian tersebut bisa diasumsikan bahwa semakin tinggi nilai kekeruhan air akan memengaruhi keasaman dari air tersebut. Selain itu, persebaran data yang terjadi selama kedua pengujian juga diperoleh bahwa hasil persebaran data pengujian sistem keseluruhan kedua lebih stabil dibandingkan dengan hasil persebaran data pengujian sistem keseluruhan pertama selama kurun waktu 24 jam.

\section{KeSIMPULAN}

Sistem monitoring keasaman dan kekeruhan dalam air layak konsumsi telah berhasil dirancang dengan mampu mengukur keasaman dan kekeruhan air dalam satu perancangan. Cara kerja perangkat bermula dari data sensor yang terbaca lalu diolah Arduino Nano. Hasil keluaran yang diolah akan ditampilkan menggunakan tampilan OLED yang kemudian dikirim menggunakan jaringan operator oleh GSM dan ditampilkan pada website Thingspeak. Sistem monitoring ini menggunakan dua sensor yaitu sensor $\mathrm{pH}$ dan sensor turbidity yang masingmasing sensornya telah terkalibrasi dengan tingkat akurasi sensor $\mathrm{pH}$ rata-rata sebesar $96,34 \%$ dan tingkat akurasi sensor turbidity sebesar $97,33 \%$. Pengiriman data yang dilakukan GSM pada sistem monitoring keasaman dan kekeruhan ini memiliki rentang yang sangat baik yaitu sebesar 95,83\% pada pengujian pertama dan sebesar $90,97 \%$ pada pengujian kedua.

\section{UCAPAN TERIMA KASIH}

Terima kasih disampaikan kepada Universitas Maritim Raja Ali Haji melalui 
Lembaga Penelitian, Pengabdian kepada Masyarakat, dan Penjaminan Mutu UMRAH yang telah membiayai Penelitian Dosen Muda ini.

\section{REFERENSI}

[1] Trumbo, P., SandraSchlicker, Yates, A. A., Poos, M., Medicine, F. and N. B. of the I. of, \& Academies, T. N. (2002). Dietary Reference Intakes For Energy, Carbohydrate, Fiber, Fat, Fatty Acids, Cholesterol, Protein, and Amino Acids. In NATIONAL ACADEMIS PRESS. https://doi.org/10.1016/s00028223(02)90346-9

[2] Suripin. (2002). Pelestarian Sumber Daya Tanah dan Air. Andi. https://books.google.co.id/books/about/Pel estarian_sumber_daya_tanah_dan_air.html ?id=JtV-AAAAMAAJ\&redir_esc=y

[3] Kemenkes. (2010). Peraturan Kementerian Kesehatan RI No. 492/Menkes/Per/IV/2010 tentang Persyaratan Kualitas Air Minum.

[4] Hardyanto, R. H. (2017). Konsep Internet Of Things Pada Pembelajaran Berbasis
Web. Jurnal Dinamika Informatika, 6(1), 87-97.

[5] Ardiansyah. (2016). Sistem Monitoring Air Layak Konsumsi Berbasis Arduino (Studi Kasus Pdam Patalassang). 1-75.

[6] Palestina, D. P. (2019). MONITORING KUALITAS AIR BERBASIS IOT (INTERNET of THINGS. 1-9. https://doi.org/.1037//0033-2909.I26.1.78

[7] Romain, S., \& Galang, M. (2015). ALAT PENDETEKSI KEKERUHAN AIR MENGGUNAKAN PARAMETER FISIKA BERBASIS MIKROKONTROLER ATMEGA8535. POLSRI REPOSITORY. http://eprints.polsri.ac.id/id/eprint/1452

[8] Saputra, A. (2016). Pengukur Kadar Keasaman Dan Kekeruhan Air. Program Studi Teknik ELektro, Universitas Muhammadiyah Surakarta, 1-20.

[9] Suryono. (2018). Teknologi Sensor : Konsep Fisis Dan Teknik Akuisisi Data Berbasis Mikrokontroler 32 Bit Atsam3X8E (Arduino Due). In Undip Press. 